\title{
RHEUMATIC COMPLAINTS IN DOCKYARD WORKERS
}

\author{
BY \\ J. A. D. ANDERSON* AND J. J. R. DUTHIE \\ E.R.C. Industrial Survey Unit, Northern General Hospital, Edinburgh
}

Studies of the prevalence of rheumatic symptoms in coalminers over the age of 15 years have been carried out by Kellgren, Lawrence, and Aitken-Swan (1953), and Anderson, Duthie, and Moody (1962). The prevalence rates recorded in these two studies were not the same and it was suggested that the difference might have arisen from differences in technique. The former workers indicated that there was no significant difference between the complaint rates for coalminers and for other industrial workers.

Preliminary observations by Duthie and Anderson (1962) showed quite a wide range of prevalence rates in different groups of workers, but most of these were ascribed to differences in the age distributions of those being studied. Numbers were small, however, and it was deemed advisable to repeat these observations in a large community, and to include skilled and unskilled workers and also those working in different environments.

It was decided that this work should be done as part of a continuing study of the social and economic effects of rheumatic disease on the working population with particular reference to work history and sickness absence. A large concern with different occupations, uniform arrangements for sickness benefit, and good medical records was sought. Such an industrial group was found at Rosyth dockyard, near Edinburgh, and permission was obtained from the Admiralty to carry out a study on a sample of the manual workers.

\section{Background and Method}

The dockyard is concerned with servicing, repairing, and refitting naval vessels. Some of the senior administrative posts are filled by naval

* Now senior lecturer in Social and Preventive Medicine at Guy's Hospital and London School of Hygiene. officers, but the majority of those working in the dockyard are civilians employed by the Admiralty. All the trades associated with the electrical and engineering industries are represented. In addition, there are maintenance workers for the buildings and equipment of the yard, and also tug men, divers, and others concerned with mooring and berthing large ships.

Many of the workers live in Dunfermline, Rosyth, Inverkeithing, or other nearby towns, but some travel from Edinburgh or from further afield, taking an hour or more for each journey. Dockyard employees, therefore, offer a wide range of working and living conditions which might throw some light on the social effects of rheumatic diseases.

The numerical strengths of all the manual occupations in the dockyard were first obtained, and these were separated into three categories. It was decided to interview all those in occupations with strengths of less than 100 , to obtain samples of at least 75 men in each of the remaining specialized occupations, and samples of at least 150 for general labourers and for those employed on small craft (seamen and stokers). The interviews and examinations continued for 4 months and, for administrative reasons, each of the six departments of the yard was treated separately. Since there were employees with similar occupations working in different departments, the sampling factors, fixed at the outset, were applied to the current nominal rolls of each department just prior to starting interviews in that department.

Each man in the sample was invited to attend for a medical interview at which a questionnaire was completed. This interview was conducted in the way which has been described by Anderson and others (1962). Those with rheumatic symptoms were examined to ascertain the cause and the severity of the disability. 
The occupation of each worker was recorded at the time of interview and subsequently the nature of the work was studied with particular reference to physical demands. The workers were divided into those who worked mainly in well-heated workshops (indoor workers) and those who worked mainly out of doors (outdoor workers). Included with the latter were those working on ships, many of which had no steam up and consequently they tended to be very cold in the winter months.

Those who had had rheumatic symptoms during the 12 months before the interview were described as "positives". Those who, although symptom-free in the past year, had had symptoms during their working lives were described as "intermediates". Those who denied having any rheumatic symptoms during their working lives were described as "negatives".

In an attempt to examine possible social consequences of rheumatic diseases in greater detail, some of those with complaints were referred to the Almoner for interview. These men were selected on the basis of one or more of three criteria:

(I) All those who had been absent from work on account of rheumatic complaints during the previous 12 months.

(2) All those who had had at least 3 weeks absence ascribed to rheumatic complaints at any time since starting work.

(3) All those who claimed that they had had to change their jobs on account of rheumatic complaints.

For every man referred in this way a control was selected who had a similar interview with the Almoner. These controls were drawn from among the negatives and the two groups were matched for age and occupation.

\section{Results}

The aggregate number of manual workers in the dockyard as stated by the six departments was 4,727. The sample lists, selected by the method described, gave a possible total of 1,490 workers, of whom 1,422 (95.4 per cent.) were interviewed. There was no evidence from the medical records in the dockyard surgery that those who refused to attend for interview would be any more or less likely to have rheumatic complaints than their colleagues. Accordingly, the results presented are based on the information obtained from those who were interviewed.

\section{Prevalence of Symptoms}

There were $522(36.7$ per cent.) out of those interviewed who were positives, of whom $173(12.2$ per cent.) had symptoms at the time of interview; a further $185(13.0$ per cent.) were classed as intermediates. The remaining $715(50.3$ per cent.) denied having had rheumatic complaints, as defined, during their working lives. Table I shows the

TABLE I

HISTORY OF RHEUMATIC COMPLAINTS

\begin{tabular}{|c|c|c|c|c|c|c|c|}
\hline \multirow{2}{*}{$\begin{array}{r}\text { Age } \\
\text { (yrs) }\end{array}$} & \multicolumn{2}{|c|}{ Positives } & \multicolumn{2}{|c|}{ Intermediates } & \multicolumn{2}{|c|}{ Negatives } & \multirow{2}{*}{$\begin{array}{c}\text { Total } \\
100 \text { per } \\
\text { cent. }\end{array}$} \\
\hline & No. & Percent. & No. & Percent. & No. & Percent. & \\
\hline $15-$ & 30 & $11 \cdot 5$ & 7 & $2 \cdot 7$ & 224 & $85 \cdot 8$ & 261 \\
\hline $25-$ & 66 & $30 \cdot 0$ & 19 & $8 \cdot 6$ & 135 & $61 \cdot 4$ & 220 \\
\hline $35-$ & 95 & $37 \cdot 4$ & 29 & $11 \cdot 4$ & 130 & $51 \cdot 2$ & 254 \\
\hline $45-$ & 184 & $51 \cdot 5$ & 57 & $16 \cdot 0$ & 116 & $32 \cdot 5$ & 357 \\
\hline $55+$ & 147 & $44 \cdot 5$ & 73 & $22 \cdot 1$ & 110 & $33 \cdot 3$ & 330 \\
\hline $\begin{array}{l}\text { All } \\
\text { Ages } \\
15+\end{array}$ & 522 & $36 \cdot 7$ & 185 & $13 \cdot 0$ & 715 & $50 \cdot 3$ & 1,422 \\
\hline
\end{tabular}

prevalence of positives, intermediates, and negatives by age. There is a clear correlation between age and the prevalence of both recent and remote symptoms up to the age of 55 years; above that age the prevalence of positives falls away, but the percentage of intermediates continues to increase. The mean age at onset of symptoms of those who were over the age of 55 at the time of interview was 45.5 years, and the combined rate for positives and intermediates above the age of 55 was less than the combined rate for those who were aged $45-54$ years at interview. This suggests either that symptoms were associated with premature retirement or that memory for symptoms occurring more than a year prior to interview was unreliable. The possibility that the memory of symptoms was voluntarily or involuntarily suppressed through fear that enforced retirement might result if such an admission was made cannot be overlooked.

It is necessary to take this relationship between age and complaint rate into account when considering the prevalence of symptoms in different occupations.

Table II (opposite) lists fifteen occupations accounting for 1,357 (95.4 per cent.) of the sample interviewed. In this table the Standardized Com- 
plaint Ratio (S.C.R.) for each occupation has been obtained from the fraction:

Observed number of positives and intermediates Expected number of positives and intermediates $\times 100$

The expected number was calculated by applying the complaint rates for the specific age groups in Table I to the numbers in each occupation using the same age distribution.

TABLE II

RHEUMATIC COMPLAINTS IN DIFFERENT OCCUPATIONS

(Standardized ratios)

\begin{tabular}{|c|c|c|c|c|c|}
\hline \multicolumn{4}{|c|}{ Occupation } & \multirow{2}{*}{$\begin{array}{c}\begin{array}{c}\text { Standardized } \\
\text { Complaint } \\
\text { Ratio* }\end{array} \\
118 \cdot 1 \\
116 \cdot 5 \\
114 \cdot 0 \\
114 \cdot 0 \\
111 \cdot 4 \\
110.9 \\
109 \cdot 9\end{array}$} & \multirow{2}{*}{$\begin{array}{c}\begin{array}{c}\text { Number of } \\
\text { Workers } \\
\text { Interviewed }\end{array} \\
115 \\
63 \\
112 \\
104 \\
77 \\
79 \\
63\end{array}$} \\
\hline $\begin{array}{l}\text { Coppersmiths } \\
\text { Stokers } \quad . \\
\text { Seamen } \\
\text { Electrical Fitters } \\
\text { Storehousemen } \\
\text { Drivers } \\
\text { Blacksmiths . . }\end{array}$ & $\begin{array}{l}\cdots \\
\cdots \\
\cdots \\
\cdots \\
\cdots\end{array}$ & $\begin{array}{l}\cdots \\
\cdots \\
\cdots \\
\cdots \\
\cdots\end{array}$ & $\begin{array}{l}\cdots \\
\cdots \\
\cdots \\
\cdots \\
\cdots \\
\cdots\end{array}$ & & \\
\hline $\begin{array}{ll}\text { Shipwrights } & \ldots \\
\text { Painters } & \ldots \\
\text { Boilermakers . . } \\
\text { Labourers } \quad \ldots \\
\text { Shipfitters } \quad . \\
\text { Machinists } & \text {. } \\
\text { Engine Fitters } \\
\text { Joiners }\end{array}$ & $\begin{array}{l}\ldots \\
\ldots \\
\ldots \\
\ldots \\
\ldots \\
\ldots\end{array}$ & $\begin{array}{l}\ldots \\
\cdots \\
\cdots \\
\cdots \\
\cdots \\
\cdots\end{array}$ & $\begin{array}{l}\cdots \\
\cdots \\
\cdots \\
\cdots \\
\cdots \\
\cdots\end{array}$ & $\begin{array}{l}96 \cdot 8 \\
95 \cdot 5 \\
94 \cdot 2 \\
90 \cdot 7 \\
88 \cdot 6 \\
88 \cdot 1 \\
73 \cdot 7 \\
69 \cdot 1\end{array}$ & $\begin{array}{r}74 \\
88 \\
73 \\
193 \\
71 \\
71 \\
101 \\
73\end{array}$ \\
\hline \multicolumn{3}{|c|}{ Other Manual Occupations } & $\ldots$ & $112 \cdot 4$ & 65 \\
\hline Total Interviewed & & & $\ldots$ & - & 1,422 \\
\hline
\end{tabular}

* For definition see text.

When similar calculations were made in respect of positives only, there was little difference in the relative positions of the different occupations; in no case was the ratio altered so as to change the position with regard to the mean value of 100 .

Seamen and stokers had high ratios but the figure for labourers, also doing heavy manual work, was low. Joiners, working mainly with dry material, had the lowest ratio, but electrical fitters, also working with dry material and in many cases working in the most modern workshop in the dockyard, had a high ratio. Coppersmiths, plumbers, and blacksmiths had high ratios, while those engaged in the similar occupation of boilermaking had a low ratio. It would thus appear that whatever correlation may exist between the complaint ratios and the occupations, it is not dependent on the heaviness of the job.

In each occupation listed there were indoor and outdoor workers. When all the indoor workers were considered together, they were found to have an S.C.R. of $99 \cdot 2$, while the outdoor workers, including those working afloat, had an S.C.R. of $100 \cdot 8$. It would thus appear that working out of doors or being exposed to cold conditions does not lead to a significant increase in the complaint rate compared with those who work in more sheltered conditions.

\section{Diagnosis}

Simple clinical examinations were made of all those who had ever had rheumatic symptoms (i.e. positives and intermediates). The findings in the different age groups are given in Table III (overleaf).

The criteria for the different diagnoses are those laid down by Anderson and others (1962) and multiple diagnoses were kept to a minimum but occurred in fourteen cases.

Rheumatoid arthritis was rarely encountered; only 21 cases $(1.5$ per cent. of those interviewed) were observed. Osteo-arthrosis was diagnosed on evidence of degenerative changes in the joints of limbs and this diagnosis was made in respect of 95 men (6.7 per cent.). The prevalence of this complaint increased with age and was only observed as a secondary complication of some other gross lesion in those under the age of 35 years. Disk disease was diagnosed in 145 workers $(10 \cdot 2$ per cent. of those interviewed). The prevalence of this condition increased gradually with age up to 45 , but then there was a sharp rise in prevalence followed by a slight decrease in those over 55 years. In addition to the cases in whom it was possible to make a firm diagnosis of disk disease there were 327 men (23.0 per cent.) who had complaints related to the neck or back to which no diagnostic label could be attached. The prevalence of these symptoms also increased with age but there was a sharp increase in these ill-defined pains after age 25 , some 20 years earlier than the similar trend observed in the prevalence of disk disease. It might be speculated that some at least of those with undetermined pains would later develop signs of disc disease. Undetermined pains in the limbs were observed in 97 (6.8 per cent.) of those who were interviewed; their prevalence increased somewhat with age up to 35 years and fell sharply in those over 55 when degenerative changes became more obvious to the clinical observer.

Other specified rheumatic diseases, mainly comprising chronic inflammatory conditions of the bursae and tendons, but including two cases of gout, accounted for 33 of those examined $(2 \cdot 3$ per cent. of the sample). 
TABLE III

DIAGNOSIS

\begin{tabular}{|c|c|c|c|c|c|c|c|c|c|c|}
\hline \multirow{2}{*}{\multicolumn{4}{|c|}{ Diagnosis }} & & \multicolumn{6}{|c|}{ Age (yrs) } \\
\hline & & & & & $15-$ & $25-$ & $35-$ & $45-$ & $55+$ & All $15+$ \\
\hline \multirow{2}{*}{ Rheumatoid Arthritis } & \multirow{2}{*}{. } & \multirow{2}{*}{$\cdots$} & \multirow{2}{*}{$\cdots$} & No. & 一 & 2 & 3 & 10 & 6 & 21 \\
\hline & & & & Per cent. & - & 0.9 & $1 \cdot 2$ & $2 \cdot 8$ & $1 \cdot 8$ & $1 \cdot 5$ \\
\hline \multirow{2}{*}{ Osteo-arthrosis } & \multirow{2}{*}{$\cdots$} & \multirow{2}{*}{$\cdots$} & \multirow{2}{*}{$\cdots$} & No. & 1 & 6 & 8 & 35 & 45 & 95 \\
\hline & & & & Per cent. & 0.4 & $2 \cdot 7$ & $3 \cdot 1$ & $9 \cdot 8$ & $13 \cdot 6$ & $6 \cdot 7$ \\
\hline \multirow{2}{*}{ Disk Disease } & \multirow{2}{*}{$\cdots$} & \multirow{2}{*}{$\cdots$} & \multirow{2}{*}{$\cdots$} & No. & 3 & 10 & 18 & 62 & 52 & 145 \\
\hline & & & & Per cent. & $1 \cdot 1$ & $4 \cdot 5$ & $7 \cdot 1$ & $17 \cdot 4$ & $15 \cdot 8$ & $10 \cdot 2$ \\
\hline \multirow{2}{*}{ Vague Pains in Back } & \multirow{2}{*}{$\cdots$} & \multirow{2}{*}{$\cdots$} & \multirow{2}{*}{$\cdots$} & No. & 19 & 46 & 62 & 98 & 102 & 327 \\
\hline & & & & Per cent. & $7 \cdot 3$ & $20 \cdot 9$ & $24 \cdot 4$ & $27 \cdot 4$ & $30 \cdot 9$ & $23 \cdot 0$ \\
\hline \multirow{2}{*}{ Vague Pains in Limbs } & \multirow{2}{*}{$\cdots$} & \multirow{2}{*}{$\cdots$} & \multirow{2}{*}{$\cdots$} & No. & 13 & 15 & 29 & 32 & 8 & 97 \\
\hline & & & & Per cent. & $5 \cdot 0$ & $6 \cdot 8$ & $11 \cdot 4$ & $9 \cdot 0$ & $2 \cdot 4$ & $6 \cdot 8$ \\
\hline \multirow{2}{*}{\multicolumn{2}{|c|}{ Other Rheumatic Diseases . . }} & \multirow{2}{*}{$\cdots$} & \multirow{2}{*}{$\cdots$} & No. & 1 & 6 & 4 & 12 & 10 & 33 \\
\hline & & & & Per cent. & 0.4 & $2 \cdot 7$ & $1 \cdot 6$ & $3 \cdot 4$ & $3 \cdot 0$ & $2 \cdot 3$ \\
\hline \multirow{2}{*}{ Unknown (not examined } & \multirow{4}{*}{$\cdots$} & \multirow{2}{*}{$\cdots$} & \multirow{2}{*}{$\cdots$} & No. & - & 1 & - & 1 & 1 & 3 \\
\hline & & & & Per cent. & 一 & $0 \cdot 5$ & 一 & $0 \cdot 3$ & $0 \cdot 3$ & $0 \cdot 2$ \\
\hline \multirow{2}{*}{ No Symptoms } & & \multirow{2}{*}{$\cdots$} & \multirow{2}{*}{$\cdots$} & No. & 224 & 135 & 130 & 116 & 110 & 715 \\
\hline & & & & Per cent. & $85 \cdot 8$ & $61 \cdot 4$ & $51 \cdot 2$ & $32 \cdot 5$ & $33 \cdot 3$ & $50 \cdot 3$ \\
\hline \multicolumn{5}{|c|}{ Total Interviewed (on which percentage is based) } & 261 & 220 & 254 & 357 & 330 & 1,422 \\
\hline
\end{tabular}

Fourteen cases of double diagnosis of whom thirteen were aged $45+$.

There were no significant differences between the rates of the different diagnoses for indoor and outdoor workers as a whole. When jobs were considered individually, there was a higher prevalence of disk disease in blacksmiths, stokers, and drivers than in other occupations, but this could be accounted for by the fact that the men in these occupations were older than the average for the yard.

\section{Effects on Working Capacity}

The functional capacity of every man was graded and Table IV (opposite) indicates that the effects of rheumatic complaints increase markedly over the age of 45 years. One hundred out of the 331 positives over the age of $45(30.2$ per cent.) had some functional limitation, compared with 24 out of 161 positives aged between 25 and 45 years (15 per cent.). Below age 25 no disabilities could be detected which would be likely to interfere with working capacity.

When indoor workers were compared with outdoor workers there was no difference in the rates for slight functional limitation. There were 43 indoor workers out of a total of 257 positives (16.7 per cent.) with such slight disabilities, and 41 out of 265 positives among outdoor workers $(15.5$ per cent.) were placed in this category. With the more severe grades, however, there was a difference between the two groups. 29 indoor workers $(11 \cdot 3$ per cent. of positives) and eleven outdoor workers (4.2 per cent. of positives) had moderate or severe limitation $\left(\chi^{2} 8.4 ; \mathrm{P}<0.01\right)$. Since the average ages of these two groups did not differ appreciably (42 and 41.8 years respectively), it is suggested that some of the more disabled workers had been transferred to indoor employment as a result of their disabilities. As far as the individual occupations were concerned, none was outstandingly different from the others.

\section{Use of Medical Services}

The use of medical services is shown in Table $\mathrm{V}$, (opposite).

Hospital treatment had been given to 183 out of the 707 positives and intermediates ( 25.9 per cent.) and 35 of these cases ( 5 per cent.) had been treated as in-patients. The ratio for hospital referral increased with advancing age up to a maximum of 
TABLE IV

\section{FUNCTIONAL GRADING}

\begin{tabular}{|c|c|c|c|c|c|c|c|c|c|c|c|}
\hline \multirow{2}{*}{\multicolumn{6}{|c|}{ Functional Grading }} & \multicolumn{6}{|c|}{ Age (yrs) } \\
\hline & & & & & & $15-$ & $25-$ & $35-$ & $45-$ & $55+$ & All $15+$ \\
\hline \multirow{2}{*}{ No symptoms } & \multirow{2}{*}{$\cdots$} & \multirow{2}{*}{$\cdots$} & \multirow{2}{*}{$\cdots$} & \multirow{2}{*}{$\cdots$} & No. & 224 & 135 & 130 & 116 & 110 & 715 \\
\hline & & & & & Per cent. & $85 \cdot 8$ & $61 \cdot 4$ & $51 \cdot 2$ & $32 \cdot 5$ & $33 \cdot 3$ & $50 \cdot 3$ \\
\hline \multirow{2}{*}{ No Limitation } & \multirow{2}{*}{$\cdots$} & \multirow{2}{*}{$\cdots$} & \multirow{2}{*}{. } & \multirow[b]{2}{*}{$\cdots$} & No. & 37 & 72 & 112 & 190 & 169 & 580 \\
\hline & & & & & Per cent. & $14 \cdot 2$ & $32 \cdot 7$ & $44 \cdot 1$ & $53 \cdot 3$ & $51 \cdot 2$ & $40 \cdot 8$ \\
\hline \multirow{2}{*}{ Slight Limitation } & \multirow{2}{*}{$\cdots$} & \multirow{2}{*}{$\cdots$} & \multirow{2}{*}{$\cdots$} & \multirow{2}{*}{$\cdots$} & No. & - & 11 & 9 & 36 & 28 & 84 \\
\hline & & & & & Per cent. & - & $5 \cdot 0$ & $3 \cdot 5$ & $10 \cdot 1$ & $8 \cdot 5$ & $5 \cdot 9$ \\
\hline \multirow{2}{*}{\multicolumn{2}{|c|}{ Moderate Limitation }} & \multirow{2}{*}{$\cdots$} & \multirow{2}{*}{$\cdots$} & \multirow{2}{*}{$\cdots$} & No. & - & 1 & 3 & 12 & 20 & 36 \\
\hline & & & & & Per cent. & - & 0.5 & $1 \cdot 2$ & $3 \cdot 4$ & $6 \cdot 1$ & $2 \cdot 5$ \\
\hline \multirow{2}{*}{ Severe Limitation } & \multirow{2}{*}{$\cdots$} & \multirow{2}{*}{$\cdots$} & \multirow{2}{*}{$\cdots$} & \multirow{2}{*}{$\cdots$} & No. & 一 & 一 & 一 & 2 & 2 & 4 \\
\hline & & & & & Per cent. & - & - & - & 0.6 & 0.6 & $0 \cdot 3$ \\
\hline \multirow{2}{*}{\multicolumn{3}{|c|}{ Unknown (not examined) . }} & \multirow{2}{*}{$\cdots$} & \multirow{2}{*}{$\cdots$} & No. & - & 1 & - & 1 & 1 & 3 \\
\hline & & & & & Per cent. & - & 0.5 & - & $0 \cdot 3$ & $0 \cdot 3$ & $0 \cdot 2$ \\
\hline \multicolumn{6}{|c|}{ Total Interviewed (on which percentage is based) } & 261 & 220 & 254 & 357 & 330 & 1,422 \\
\hline
\end{tabular}

TABLE V

USE OF MEDICAL SERVICES

\begin{tabular}{|c|c|c|c|c|c|c|c|c|}
\hline \multirow{2}{*}{\multicolumn{3}{|c|}{ Medical Service }} & \multicolumn{6}{|c|}{ Age (yrs) } \\
\hline & & & $15-$ & $25-$ & $35-$ & $45-$ & $55+$ & All $15+$ \\
\hline \multirow{4}{*}{$\begin{array}{l}\text { Hospital Treatment } \\
\text { at Any Time }\end{array}$} & \multirow{2}{*}{ In-patient } & No. & 1 & 3 & 6 & 16 & 9 & 35 \\
\hline & & Per cent. & $2 \cdot 7$ & $3 \cdot 5$ & $4 \cdot 8$ & $6 \cdot 6$ & $4 \cdot 1$ & $5 \cdot 0$ \\
\hline & \multirow{2}{*}{ Out-patient } & No. & 4 & 18 & 18 & 64 & 44 & 148 \\
\hline & & Per cent. & $10 \cdot 8$ & $21 \cdot 2$ & $14 \cdot 5$ & $26 \cdot 6$ & $20 \cdot 0$ & $20 \cdot 9$ \\
\hline \multirow{2}{*}{\multicolumn{2}{|c|}{ Treatment by Family Doctor in Past Year }} & No. & 9 & 29 & 31 & 63 & 65 & 197 \\
\hline & & Per cent. & $24 \cdot 3$ & $34 \cdot 1$ & $25 \cdot 2$ & $26 \cdot 1$ & $29 \cdot 5$ & $27 \cdot 9$ \\
\hline \multirow{2}{*}{\multicolumn{2}{|c|}{ Self Treatment in Past Year }} & No. & 4 & 16 & 31 & 53 & 42 & 146 \\
\hline & & Per cent. & $10 \cdot 8$ & $18 \cdot 8$ & $25 \cdot 0$ & $22 \cdot 0$ & $19 \cdot 1$ & $20 \cdot 7$ \\
\hline \multicolumn{3}{|c|}{ Total with Complaints (on which percentage is based) .. } & 37 & 85 & 124 & 241 & 220 & 707 \\
\hline
\end{tabular}

$33 \cdot 2$ per cent. for those between 45 and 54 years, but fell to $24 \cdot 1$ per cent. for those above this age, suggesting that older workers with complaints serious enough to warrant hospital referral had had to leave the dockyard prematurely.

Medical treatment for rheumatic complaints from general practitioners had been obtained by 197 of the 707 affected workers $(27.8$ per cent.) during the year before interview and a further $146(20.7$ per cent.) had treated themselves without medical consultation during the same period. The peak prevalence of consultation with the family doctor occurred between 25 and 34 years $(34 \cdot 1$ per cent.) and of self-medication between 35 and 44 years (25.0 per cent.).

\section{Sickness Absence}

Sickness absence ascribed to rheumatic causes accounted for a total of 482 weeks during the year 
preceding interview-an average of 33.9 weeks per 100 workers interviewed. The number of weeks lost from this cause and the rates per cent. for each age group are shown in Table VI. The maximum rate of $52 \cdot 1$ weeks per cent. occurred in those between 45 and 54 years of age, while those in the decade below this had a rate of only 23.2 weeks per cent. Sickness absence from other causes during the same period amounted to 3,274 weeks and the rates for the different age groups are also shown in the Table. The maximum loss occurred in those over 55 years (290 weeks per 100 workers), while those between 35 and 44 years had a rather lower rate (174 per 100 workers) than the decades above and below.

In order to assess the importance of absence due to rheumatic causes in the overall pattern, the absence rates for 522 positives were compared with those for a group of negatives selected on the basis of comparable age structure. The positives had a total annual absence of 1,731 weeks (an average of 3.3 weeks per man per annum). The same group was absent for a total of $\mathbf{4 8 2}$ weeks from rheumatic causes and 1,249 (average 2.4) from other causes: the negative group had a total annual absence of 829 weeks (average 2.5). As far as absence from sickness other than rheumatism was concerned, it would appear, therefore, that the two groups were similar with regard to sickness absence from causes other than rheumatism, and it can be fairly assumed that rheumatic complaints are a real and independent cause of absence, and that the diagnosis of "rheumatism" is not used merely as a substitute for some other diagnosis.

Sickness absence rates varied from job to job. Table VII shows the total numbers of weeks absence on account of rheumatism and also the crude rates per 100 interviewed. The effect of age on these rates has been taken into account by calculating a standardized ratio similar to that used to calculate the S.C.R. The effect of using such a ratio is to exaggerate the differences between one occupation and another. However, the order of the occupa-

TABLE VI

SICKNESS ABSENCE

\begin{tabular}{|c|c|c|c|c|c|c|c|c|c|}
\hline \multirow{2}{*}{\multicolumn{4}{|c|}{ Sickness Absence }} & \multicolumn{6}{|c|}{ Age (yrs) } \\
\hline & & & & \multirow{2}{*}{$\frac{15-}{17}$} & \multirow{2}{*}{$\begin{array}{r}25- \\
74\end{array}$} & \multirow{2}{*}{$\frac{35-}{59}$} & \multirow{2}{*}{$\frac{45-}{186}$} & \multirow{2}{*}{$\frac{55+}{146}$} & \multirow{2}{*}{$\frac{\text { All } 15+}{482}$} \\
\hline Dhoumatis & & Total Weeks in Year & $\ldots$ & & & & & & \\
\hline Nneumatic $\quad$. & $\cdots$ & Rate per 100 Interviewed & $\ldots$ & $6 \cdot 5$ & $33 \cdot 6$ & $23 \cdot 2$ & $52 \cdot 1$ & $44 \cdot 2$ & $33 \cdot 9$ \\
\hline \multirow{2}{*}{ Other Causes } & \multirow[b]{2}{*}{. } & Total Weeks in Year & $\cdots$ & 472 & 404 & 442 & 999 & 957 & 3,274 \\
\hline & & Rate per 100 Interviewed & $\cdots$ & $180 \cdot 8$ & $183 \cdot 6$ & $174 \cdot 0$ & $279 \cdot 8$ & $290 \cdot 0$ & $230 \cdot 2$ \\
\hline \multirow{2}{*}{ All Causes . } & \multirow{2}{*}{$\cdots$} & Total Weeks in Year & $\cdots$ & 489 & 478 & 501 & 1,185 & 1,103 & 3,756 \\
\hline & & Rate per 100 Interviewed & $\ldots$ & $187 \cdot 4$ & $217 \cdot 3$ & $197 \cdot 2$ & $331 \cdot 9$ & $334 \cdot 2$ & $264 \cdot 1$ \\
\hline \multicolumn{2}{|c|}{ No. of Men Interviewed } & . & $\ldots$ & 261 & 220 & 254 & 357 & 330 & 1,422 \\
\hline
\end{tabular}

TABLE VII

SICKNESS ABSENCE FROM RHEUMATIC CAUSES

\begin{tabular}{|c|c|c|c|c|c|c|c|c|}
\hline \multicolumn{4}{|c|}{ Occupation } & $\begin{array}{c}\text { Total Weeks } \\
\text { Absence in Year }\end{array}$ & $\begin{array}{c}\text { Rate per } 100 \\
\text { Interviewed }\end{array}$ & $\underset{\text { Ratio }}{\text { Standardized }}$ & $\begin{array}{c}\text { No. of Men } \\
\text { Absent in Year }\end{array}$ & $\begin{array}{c}\text { No. of Workers } \\
\text { Interviewed }\end{array}$ \\
\hline $\begin{array}{l}\text { Driver } \\
\text { Shipwright ... } \\
\text { Ship Fitter . } \\
\text { Electrical Fitter } \\
\text { Joiner } \\
\text { Engine Fitter } \\
\text { Storehouseman } \\
\text { Boilermaker } \\
\text { Seaman } \quad . \\
\text { Stoker } \quad \ldots \\
\text { Machinist . } \\
\text { Labourer . } \\
\text { Coppersmith } \\
\text { Blacksmith . . } \\
\text { Painter } \quad .\end{array}$ & $\begin{array}{l}\ldots \\
\cdots \\
\cdots \\
\cdots \\
\cdots \\
\cdots \\
\ldots \\
\cdots \\
\cdots \\
\cdots \\
\cdots\end{array}$ & $\begin{array}{l}\ldots \\
\cdots \\
\cdots \\
\cdots \\
\cdots \\
\cdots \\
\cdots \\
\cdots \\
\cdots \\
\cdots\end{array}$ & $\begin{array}{l}\cdots \\
\cdots \\
\cdots \\
\cdots \\
\cdots \\
\cdots \\
\cdots \\
\cdots \\
\cdots \\
\cdots \\
\cdots \\
\cdots \\
.\end{array}$ & $\begin{array}{r}4 \\
4 \\
4 \\
10 \\
11 \\
14 \\
12 \\
12 \\
34 \\
21 \\
26 \\
88 \\
53 \\
55 \\
72\end{array}$ & $\begin{array}{l}5 \cdot 1 \\
5 \cdot 4 \\
5 \cdot 6 \\
9 \cdot 6 \\
15 \cdot 1 \\
13 \cdot 9 \\
15 \cdot 6 \\
16 \cdot 4 \\
30 \cdot 4 \\
33 \cdot 3 \\
36 \cdot 6 \\
45 \cdot 6 \\
46 \cdot 1 \\
87 \cdot 3 \\
81 \cdot 8\end{array}$ & $\begin{array}{l}12 \cdot 3 \\
22 \cdot 1 \\
23 \cdot 4 \\
38 \cdot 8 \\
41 \cdot 5 \\
45 \cdot 8 \\
46 \cdot 7 \\
48 \cdot 4 \\
78 \cdot 3 \\
93 \cdot 3 \\
100 \cdot 0 \\
118 \cdot 8 \\
160 \cdot 1 \\
208 \cdot 3 \\
236 \cdot 1\end{array}$ & $\begin{array}{r}1 \\
1 \\
2 \\
3 \\
3 \\
4 \\
5 \\
6 \\
6 \\
7 \\
6 \\
20 \\
8 \\
5 \\
6\end{array}$ & $\begin{array}{r}79 \\
74 \\
71 \\
104 \\
73 \\
101 \\
77 \\
73 \\
112 \\
63 \\
71 \\
193 \\
115 \\
63 \\
88\end{array}$ \\
\hline \multicolumn{2}{|c|}{ Other Occupations } & . & $\ldots$ & 62 & $95 \cdot 4$ & $256 \cdot 2$ & 4 & 65 \\
\hline \multicolumn{3}{|c|}{ All Manual Occupations ... } & $\ldots$ & 482 & $33 \cdot 9$ & - & 87 & 1,422 \\
\hline
\end{tabular}


tions which have been listed in order of increasing standardized ratios would be virtually unaltered if the list had been compiled in order of increasing crude rates of absence.

Coppersmiths, blacksmiths, painters, and labourers had high rates of absence. Seamen, stokers, and machinists were fairly near the mean rate. The other named occupations had low rates.

Crude rates of absence attributed to rheumatic diseases were $35 \cdot 4$ and $32 \cdot 2$ for indoor and outdoor workers respectively, while the expected rates, allowing for age, were $34 \cdot 3$ and $33 \cdot 4$. It would therefore appear that, while those in certain occupations have more absence from rheumatic causes than others, the contrast between indoor and outdoor working conditions plays little part in determining the rates of absence.

\section{Other Social Effects}

Each man was asked about his work history to find out if he had had to change his job because of ill health and the details of such changes were noted. There were 88 out of 522 positives (16.9 per cent.) who had changed jobs because of ill health and in 29 cases ( 5.6 per cent.) one of the rheumatic diseases was given as the reason. This left a total of 59 cases $(11 \cdot 3$ per cent.) in which the change was attributed to ill health of some other kind. In 329 negatives with the same age structure as the positives, there were 33 men (10 per cent.) who claimed that they had had to change jobs because of ill health; it seems therefore that changes attributed to rheumatism were additional to those attributed to other causes of ill health.

In order to study the effects on social conditions and the family as a whole, a special group of 201 workers was studied. These men were considered most likely to have experienced some socio-economic effect from their complaints, since they fell into one of the three categories of sickness absence or change of employment already described. Each man was matched for age and occupation with a negative control and comparison of the two groups showed little difference in respect of most factors.

In each there were 185 (92 per cent.) living in a modern home with a bath. $172(85.6$ per cent.) of the positive group were married at the time of interview as against $154(76.6$ per cent.) of the controls. The difference here is significant $\left(\chi^{2} 4 \cdot 7\right.$; $P<0.05>0.02)$, but without more detailed information it would be unwise to draw conclusions from this.

Among the married positives, there were $41(23 \cdot 8$ per cent.) whose wives were working while among the married controls there were $39(25 \cdot 2$ per cent.) whose wives were working. Other factors, such as number of children, duration of travel, and recent change of home were studied in these two groups, but no differences could be detected.

\section{Discussion}

This study is based on information obtained from 1,422 workers in the Admiralty dockyard employed in several different jobs. The indices of sickness absence, change of job, and various environmental and home factors have been used in an attempt to assess the social and economic effects of rheumatic complaints.

The sickness absence rates, unlike the complaint rates, varied considerably from one occupation to another. The average sickness absence from rheumatic causes of 35 weeks per 100 workers per annum was lower than that for coalminers ( 51 weeks). There was a suggestion that those in the heavier jobs, such as blacksmiths, coppersmiths, and labourers, had higher sickness rates than fitters of one kind or another and joiners. The majority of painters interviewed were concerned with bulk painting of ships rather than the more delicate sign painting; it is therefore understandable that their absence rate from rheumatic causes was similar to those of other heavy workers.

It has again been demonstrated that sickness absence ascribed to rheumatism occurred in addition to that from other causes, but retrospective studies of sickness absence tend to be unsatisfactory since the duration may not be accurately reported. Further work with this sample includes a follow-up for a period of one year in an attempt to obtain more accurate records. The rate of sickness absence may be affected by the worker continuing in his present employment or changing to another, and no information is yet available on those who left the dockyard. The results recorded here, based on information from those still employed in the yard, indicate that changes of job ascribed to rheumatism by the affected person occur in addition to those ascribed to other medical causes.

The use of medical services and self medication are of interest. Those with rheumatic complaints consult their doctors in increasing numbers up to the age of 35 years but thereafter the rate falls away. The use of self medication continues to increase for a further 10 years but again falls away 
in the older age groups. This suggests that those who are affected either come to terms with their complaints or develop a hopeless resignation that the medical services can do little better than their own remedies, followed by a realization that even these are of little avail.

Comparison between a survey of this nature and similar studies by other workers can be of only limited value since the techniques employed may be different. In comparing this study with our previous observations, however, this argument is of less account since the techniques and the observers were the same. It is therefore noteworthy that the prevalence of rheumatic symptoms during the year before interview was 36.7 per cent. in the present sample, whereas $47 \cdot 1$ per cent. of a sample of coalminers were similarly affected (Anderson and others, 1962). This difference occurred in spite of the fact that dockyard workers were older on the average than the sample of coalminers.

No appreciable differences could be detected between the complaint rates of the several occupations within the dockyard, nor in the rates of the different types of colliery workers. It would appear, therefore, that there is a difference between the overall complaint rates of the two industries and further observations of these and of other industries will be made to try and discover the reasons.

It is possible that psychological factors may have a bearing on the difference in complaint rates between coalminers and dockyard workers. Further studies in other industries might help to clarify this point, but the time required for a psychological interview would be greater than that which was needed for this study, and it may be difficult to persuade either the industries or the employees themselves to devote time to lengthy interviews on this scale. The social indices of housing standard, number of children, and whether or not the wives were working, showed little difference between the affected sample and the controls, though it does appear that affected workers are more likely to be married than their unaffected colleagues of the same age. The statistical significance of this difference is small but the observation poses a further psychological question.

\section{Summary}

(1) A sample of 1,422 dockyard employees has been assessed and it has been found that 37 per cent. of them had had rheumatic complaints during the previous year.

(2) Complaint rates, though varying with occupation, did not appear to be related to the heaviness of the work involved nor did indoor workers differ from outdoor workers in this respect.

(3) Sickness absence ascribed to rheumatism accounted for 35 weeks per 100 workers during the previous year. This rate was higher in the heavier manual occupations than in the lighter ones.

(4) A change of occupation ascribed to rheumatic causes had been made by 6 per cent. of those affected. Changes ascribed to other forms of ill health had occurred to the same extent in positives and negatives.

(5) The place of psychological factors in influencing the prevalence of rheumatic complaints in different industries, and also the social effects of these complaints, is discussed.

We wish to express our gratitude to the Empire Rheumatism Council for financing this project, to Miss Beryl Moody, medical social worker, and to Mrs. C. Johnston, secretary to the Unit. Dr. E. Lewis-Faning gave helpful advice in planning the survey. We are also grateful for the help and co-operation of Admiral Alleyn and the staff of H.M. Dockyard, Rosyth, and to all the employees who agreed to take part.

\section{REFERENCES}

Anderson, J. A. D., Duthie, J. J. R., and Moody, B. P (1962). Ann. rheum. Dis., 21, 342.

Duthie, J. J. R., and Anderson, J. A. D. (1952). Arch. environ. Hlth, 4, 511.

Kellgren, J. H., Lawrence, J. S., and Aitken-Swan, J. (1953). Ann. rheum. Dis., 12, 5.

\section{Manifestations rhumatismales parmi les ouvriers} de construction de navires

\section{RÉSUMÉ}

(1) Une enquête parmi 1.422 ouvriers de construction de navires révéla que 37 pour cent d'entre eux avait présenté des manifestations rhumatismales au cours de l'année passée.

(2) La proportion de telles manifestations, bien que différente selon le genre d'occupation, n'était pas influencée par le travail, dur ou non, à l'abri ou en plein air.

(3) Pendant l'année passée l'absence pour maladie attribuée au rhumatisme fut de 35 semaines par 100 ouvriers. Ce chiffre fut plus grand pour les travaux manuels durs que pour les légers.

(4) Un changement d'occupation pour des causes attribuées au rhumatisme eut lieu chez 6 pour cent de ceux affectés. Des changements d'occupation attribués à d'autres maladies se produisirent dans la même proportion des rhumatisants que des non-rhumatisants. 
(5) On discute le rôle des facteurs psychologiques dans la fréquence des manifestations rhumatismales dans de différentes industries, ainsi que l'effet social de ces manifestations.

\section{Manifestaciones reumáticas entre obreros de construcción naval}

\section{SUMARIO}

(1) Una investigación de 1.422 obreros de astillero reveló que un 37 por ciento de ellos presentó síntomas de reumatismo durante el año pasado.

(2) La proporción de tales manifestaciones, aunque diferente para varias ocupaciones, fué sin relación con la forma del trabajo, que este sea duro o no, interior o al aire libre.

(3) Durante el año pasado ausencias por enfermedad atribuida al reumatismo fueron de 35 semanas por 100 obreros. Estas cifras fueron mayores para trabajos manuales duros que para los fáciles.

(4) Cambios de ocupación por causas atribuidas al reumatismo ocurrieron en un 6 por ciento de los afectos. Cambios de ocupación atribuidos a otras enfermedades ocurrieron en una proporción igual para los con y los sin síntomas de reumatismo.

(5) Se discute el papel de factores psicológicos en la incidencia de manifestaciones reumáticas en diferentes industrias, así como el efecto social de estas manifestaciones. 